\title{
ATHLETES'JUSTIFICATION OF CHEATING IN SPORT: RELATIONSHIP WITH MORAL DISENGAGEMENT IN SPORT AND PERSONAL FACTORS
}

\author{
Saulius Šukys \\ Lithuanian Sports University, Kaunas, Lithuania
}

\begin{abstract}
Research background and hypothesis. The research focus is on university athletes' justification of cheating in sport. We hypothesised that moral disengagement would be more linked to more favourable evaluations of cheating in sports activities among athletes. Secondly it was hypothesised that justification of cheating in sport would be linked to gender and, accordingly, it would not be associated with experience in sport.

Research aim was to reveal the dependence of the athletes' assessment of cheating in their sports activities and moral disengagement in sport considering their personal factors

Research methods. The sample included 338 (246 male and 92 female) athletes recruited from Lithuanian universities.The participants completed the Justification of Deception in Sport Scale (Sukys, Nickus, 2010) and the Moral Disengagement in Sport Scale-Short (MDSS-S; Boardley, Kavussanu, 2008).

Research results. The regression analyses showed that gender of athletes was a significant predictor for justification of cheating in sport $(\beta=0.15, \mathrm{p}<0.01)$ as male student athletes more justified cheating in sport. Years of involvement in sport were not related with overall justification of cheating in sport. Moral disengagement in sport was a predictor for the overall justification of cheating in sport $(\beta=0.35, \mathrm{p}<0.001)$.

Discussion and conclusions. Our study revealed the relationship between moral disengagement in sport and athletes' justification of cheating in sport. Analysing different forms of cheating it was found that moral disengagement in sport was a stronger predictor for the justification of such deceptive actions that are linked to athletes' manipulation of the rules of the sports and manipulation with the results of the sports contest. It was established that male student athletes more justified cheating in sport. Research results did not reveal relationship between overall justifications of cheating by years of involvement in sport. However, the analysis of the justification of different forms of cheating showed that students with less sports experience more justified deceptive actions linked to the manipulation with the results of the sports contest, and, on the contrary, less justified other forms of cheating in sport.
\end{abstract}

Keywords: sport, justification of cheating in sport, moral disengagement in sport.

\section{INTRODUCTION}

$\mathrm{T}$ raditionally sport is thought to contribute to social progress, harmony and peace, promote mutual respect and understanding, bring people together and mobilize them for common activities. On the other hand, the attitudes towards sport and its values have been changing in modernizing society (Budreikaitè, Adaškevičienè, 2010). In this way traditional values in sport give way to consumer values (Genys, 2011). It is therefore not surprising that seeking victory at any cost does not avoid cheating. S. Zaksaite (2012 a) named cheating in sport as one of black sides of sport which reveals its negative image. Though cheating is unevenly widespread in different sports, certain forms of it are typical of most branches of sport. According to P. G. Mewett (2002) "cheating, it seems, occurs in all sports. This is not to claim that all sports players cheat, but rather that each sport contains some who cheat" (p. 292). 
Most often cheating is attributed to unfair behaviour when athletes aim to win or gain an advantage over competitors, or during an examination or performing a task (Hsu, 1997). Cheating is an attempt to gain an advantage by violating the shared interpretation of the basic rules (the ethos) of the parties engaged without being caught and held responsible for it. The goal of the cheater is that the advantage gained is not eliminated as compensated for (Loland, 2002, p. 96). It should be noted that cheating is not only violating the rules. As L. Hsu states (1997), breaking rules is not sufficient for cheating, and breaking rules is not necessary for cheating. Research literature also deals with the concept of deception. Deception involves "making someone believe something that is not true in order to get what you want" (Hsu, 1997, p. 167). In this sense deception is one of the necessary elements of cheating in sport. Thus, in our work we will use the term cheating, and not deception.

In research literature the phenomenon of cheating in sport is more analysed in the theoretical aspect (Hsu, 1997; Fraleigh, 2003; Loland, 2005). Legal aspects of cheating in sport have also been researched (Zaksaite, 2012 b). However, there is a lack of empirical studies and herewith research instruments to investigate cheating in sports activities. Athletes' perception of cheating in their sports activities (Moran et al., 2004), as well as coaches' attitudes towards cheating in sport (Sukys, Nickus, 2010) have been investigated. Some specific forms of cheating have also received researchers' attention, for example, the effect of deception and non-deception penalty kick strategies on goalkeeping performance (Dicker et al., 2011). Though deception in sport manifests in different forms and not necessarily only athletes cheat, in our research we primarily raised the question how this phenomenon was assessed by athletes themselves. On the other hand, researchers try to explain why people get engaged in negative behaviours. Thus, it is relevant to establish not only how athletes evaluate cheating in their sports activities, but also factors determining those evaluations. In recent years studies in negative behaviours of athletes including cheating also deal with moral disengagement in sport context. The theory of A. Bandura (1991) suggests that people are able to violate personal standards without self-sanction through the selective use of eight psychosocial manoeuvres known as mechanisms of moral disengagement. These mechanisms allow individuals to transgress without experiencing negative affect, thereby decreasing constraint on future negative behaviour. Research data suggest that moral disengagement has strong positive relationship with antisocial behaviour towards both teammates and opponents (Boardley, Kavussanu, 2007; 2009). Also it was established that moral disengagement mediated relationship between controlled motivation and antisocial behaviour towards teammates and opponents (Hodge, Lonsdale, 2011). So, we hypothesise that moral disengagement will be more linked with more favourable evaluations of cheating in sports activities among athletes. Research data dealing with athletes' values (Sukys, Jansoniené, 2012), moral disengagement in sport (Boardley, Kavussaanu, 2007) indicate differences in the aspect of gender. Respectively, previous research suggests that sports experiences are not associated with antisocial behaviour (Boardley, Kavussanu, 2010) and that sports experiences are not related with moral disengagement in sport (Sukys, Jansoniene, 2012). So, the study evaluated athletes' personal factors and the second hypothesis was that justification of cheating in sport would be linked to gender (male athletes would more justify it) and, accordingly, it would not be associated with experience in sport. In order to verify the hypotheses, our research aim was to reveal the dependence of the athletes' assessment of cheating in their sports activities and moral disengagement in sport considering their personal factors.

\section{RESEARCH METHODS}

Research participants. The sample included 338 (246 male and 92 female) athletes recruited from Lithuanian universities. The condition of athletes' participation in our research was previous participation in a championship of the country, i. e. we tended to recruit athletes of higher sports mastery levels. For that reason we applied purposive sampling. Among the athletes who participated in this study, $47.6 \%(\mathrm{n}=161)$ noted that they were prize-holders in the national championship, 20.4\% $(n=69)$ of them participated in the European Championship and 5.6\% $(\mathrm{n}=$ 19) - in the World Championship. While analysing the data athletes were divided into two groups by their sports mastery: National level - who participated only in the national championship $(\mathrm{n}=$ 259) and International level - who participated 
in European or World Championship $(n=79)$. Among the research participants, $63.2 \%$ of them played various ball games (basketball, volleyball, handball and football), $10.90 \%$ were in track and field events, and $25.9 \%$ were in other sports, mainly in individual sports. The average years of involvement in their current sport was 9.33 $(\mathrm{SD}=3.38)$. While analyzing the data athletes were divided into three groups based on percentiles of their sport experience: $\geq 7$-year experience $(\mathrm{n}=96), 8-11$ years of sports experience $(\mathrm{n}=140)$, and $\leq 12$ years of sports experience $(n=102)$.

Measures. The survey-style assessment questionnaire was used in this study and it contained three sections. The first requested the participants' gender, most recent sport, level of sports mastery and years of involvement in that sport. The other sections assessed athletes' justification of cheating in sport and moral disengagement in sport.

The Justification of Deception in Sport Scale (JDSS). While analysing athletes' justification of cheating in sport we used previously applied scale for coaches' (Sukys, Nickus, 2010). The scale consisted of 19 statements describing various cases of cheating. Athletes had to indicate the degree of how such behaviour could be justified from 1 (the behaviour is totally indefensible) to 5 (such behaviour can always be justified). In the study mentioned above, five factors describing different forms of cheating in sport have been identified based on the survey of coaches. Since this study analysed students engaged in sports activities, it was decided to re-check the structure of the scale.

The Moral Disengagement in Sport ScaleShort (MDSS-S; Boardley, Kavussanu, 2008). This eight item scale measured overall construct of moral disengagement in sport. Items were rated on a 7-point scale anchored by strongly disagree (1) and strongly agree (7). Examples of items were "It is okay for players to lie to officials if it helps their team", "Shouting at an opponent is okay as long as it does not end in violent conduct". Although this scale was a unidimensional measure of sport moral disengagement, it still had items measuring eight of the mechanisms of moral disengagement. However, in this study overall sport moral disengagement was of interest. Alpha coefficient for overall scale was 0.69 .

Statistical analysis. First, factor analysis was conducted for Deception in Sport Scale. Then descriptive statistics analyses and internal consistency were examined by conducting
Cronbach's alpha analyses. T-tests and oneway ANOVA were computed to compare group differences. Pearson's correlation analyses were conducted to examine the interrelations between justification of cheating in sport and moral disengagement in sport scales. Multiple regression analyses were performed to test relationships between athletes' justification of cheating in sport, moral disengagement in sport, and personal factors. All statistics was conducted by SPSS 19.0 software.

\section{RESEARCH RESULTS}

Analysing the findings of student athletes' justification of cheating in sports activities, first principal components analysis with varimax rotation and Kaiser Normalization were conducted. The factor analysis $(\mathrm{KMO}=0.83$, Bartlett's test of Sphericity was $=1646.00, p=0.001$ ) produced five factors accounting for $56.34 \%$ of variance. Items with loadings lower than 0.40 and items with similar loadings on more than one factor must be eliminated to obtain a clear solution and improve the independence of factors (Kahn, 2006). Since there were no such statements, we took into account how many statements the factor included. As two factors consisted of only two statements, the final solution included 15 items. Repeated factor analysis $(\mathrm{KMO}=0.83$, Bartlett's test of Sphericity was $=1338.78, \mathrm{p}=0.001$ ) produced three factors explaining $51.99 \%$ of variance (Table 1). The first factor indicated behaviours associated with the manipulation with the results of the sports contest (e. g. "The head of the team settled with the judges about the decisions favourable for the team (or athlete)"). The second factor was linked with the athlete manipulation of the rules of the sports contest (e. g. "Athletes hold the opponent by his/ her clothes trying to limit his/ her actions"). The third factor included behaviours when the athlete provoked the opponent to take certain actions (e. g. "During the competition athletes try to overbalance the leader of the opposing team psychologically aiming at making him/ her violate the rules"). Those three factors were entitled as the three forms of deception in sports.

Descriptive statistics and correlations were computed using the entire sample and presented in Table 2. Students engaged in sports mainly justified the third form of cheating. For example, $12.5 \%$ of the respondents indicated that such actions when in the contest athletes try to mentally put the 


\begin{tabular}{|l|c|c|c|}
\hline \multirow{2}{*}{ Statements of the scale } & \multicolumn{3}{|c|}{ Factors } \\
\cline { 2 - 4 } & Factor 1 & Factor 2 & Factor 3 \\
\hline Statement 9 & 0.71 & & \\
\hline Statement 10 & 0.70 & & \\
\hline Statement 4 & 0.66 & & \\
\hline Statement 3 & 0.63 & & \\
\hline Statement 7 & 0.60 & & \\
\hline Statement 11 & 0.59 & & \\
\hline Statement 6 & 0.53 & & \\
\hline Statement 16 & & 0.76 & \\
\hline Statement 15 & & 0.71 & \\
\hline Statement 18 & & 0.71 & \\
\hline Statement 19 & & 0.68 & \\
\hline Statement 17 & & 0.67 & \\
\hline Statement 13 & & & 0.72 \\
\hline Statement 8 & & & 0.71 \\
\hline Statement 14 & & & 0.61 \\
\hline Cumulative \% & & 40.40 & 51.99 \\
\hline
\end{tabular}

Table 1. Items and factor loading for JDSS $(\mathbf{n}=338)$

Note. $* *-p<0.01$. Factor $1-$ Manipulation with the results of the sports contest (MRSC). Factor 2 - Athletes' manipulation with the rules of the sports contest (AMRSC). Factor 3 - Provocation against competitors (PAC).

\begin{tabular}{|l|c|c|c|c|c|}
\hline \multicolumn{1}{|c|}{ Variables } & $\mathbf{1}$ & $\mathbf{2}$ & $\mathbf{3}$ & $\mathbf{4}$ & $\mathbf{5}$ \\
\hline 1. MRSC & $(0.76)$ & & & & \\
\hline 2. AMRSC & $0.27^{* *}$ & $(0.78)$ & & & \\
\hline 3. PAC & $0.12^{*}$ & $0.43^{* *}$ & $(0.63)$ & & \\
\hline 4. JDSS & $0.71^{* *}$ & $0.80^{* *}$ & $0.63^{* *}$ & $(0.79)$ & \\
\hline 5. Moral disengagement & $0.24^{* *}$ & $0.33^{* *}$ & $0.17^{* *}$ & $0.36^{* *}$ & $(0.69)$ \\
\hline Mean & 1.60 & 2.49 & 2.99 & 2.17 & 3.46 \\
\hline Standard deviation & 0.62 & 0.84 & 0.93 & 0.55 & 1.09 \\
\hline
\end{tabular}

Table 2. Correlations, reliability estimates, and descriptive statistics for the JDSS and MDSS-S $(\mathbf{n}=\mathbf{3 3 8})$

Note. MRSC - Manipulation with the results of the sports contest, AMRSC - athletes' manipulation with the rules of the sports contest, PAC - Provocation against competitors, JDSS - Justification of deception in sport scale (overall). ${ }^{*}-\mathrm{p}<0.05, * *-\mathrm{p}<0.01$. Alpha coefficients are reported on the diagonal.

rival leader out of balance in order to force him/ her to violate the rules could always be justified, $20.1 \%$ of subjects maintained that such actions could be justified most often. Mean value for moral disengagement in sport shows that athletes more often tend to choose neutral position when evaluating eight statements related with behaviour in sport. Significant correlations were found between all three types of cheating. As it was hypothesized, justification of cheating in sport was related with moral disengagement in sport. Also significant negative correlation was established between years of involvement in sport and the first form $(r=-0.12, p<0.05)$, and positive correlation was found with the second $(r=0.17, p<0.01)$ and the third forms of cheating $(r=0.12, p<0.05)$. Significant correlation between athletes' mastery and three forms of cheating was not established.
Next we explored differences by athletes' gender, mastery and years of involvement in sport. The mean scores of males' justification of cheating in sport were significantly higher than those of females on the second factor $(\mathrm{M}=2.60$, $\mathrm{SD}=0.85$ and $\mathrm{M}=2.20, \mathrm{SD}=0.76 ; \mathrm{t}(336)=-3.94$, $\mathrm{p}<0.01)$ and the third factor $(\mathrm{M}=3.06, \mathrm{SD}=0.92$ and $\mathrm{M}=2.82, \mathrm{SD}=0.94 ; \mathrm{t}(336)=-2.09, \mathrm{p}<0.05)$. Also it was established that the mean scores of males' overall justification of the cheating in sport were significantly higher than those of females $(\mathrm{M}=2.22, \mathrm{SD}=0.56$ and $\mathrm{M}=2.04, \mathrm{SD}=0.48$; t $(336)=-2.77, p<0.01)$. Research results did not reveal statistically significant differences comparing overall moral disengagement in sport by gender. There were no statistically significant differences comparing results by athletes' mastery levels. 
ANOVA indicated the differences of years of involvement in sport in dependence on justification of the first form of cheating $(\mathrm{F}(2,336)=5.00$, $\mathrm{p}<0.01)$. The Turkey test found that the means for $\geq 7$-year involvement in sport, and eight to 11 years of involvement in sport were statistically significantly different from each other $(\mathrm{M}=1.76$, $\mathrm{SD}=0.72$ and $\mathrm{M}=1.51, \mathrm{SD}=0.50 ; \mathrm{p}<0.01)$, and that there were no other statistically significant differences comparing the mean values between other groups of athletes. ANOVA indicated the differences in the years of involvement in sport on justification of the second form of cheating in sport respectively $(F(2,336)=5.51, p<0.01)$. The Turkey test found that the means for $\geq 7$-year involvement in sport and 12 to 20 years of involvement in sport were statistically significantly different from each other $(\mathrm{M}=2.26, \mathrm{SD}=0.82$ and $\mathrm{M}=2.65, \mathrm{SD}=0.84$; $\mathrm{p}<0.01$ ), and that there were no other statistically significant differences comparing the mean values between other groups of athletes. Research results did not reveal statistically significant differences comparing overall justification in sport by years of involvement in sport.

The regression analyses were performed to examine the effects of personal factors (gender and years of involvement in sport), moral disengagement in sport on justification of cheating in sport. In each analysis, personal factors of gender, years of involvement in sport, and moral disengagement in sport were included as independent variables while justification of the three forms of cheating and overall cheating - as dependent variables. As we can see in Table 3, gender of athletes was a significant predictor for justification of the second $(\beta=0.15, p<0.01)$ and the third $(\beta=0.13$, $p<0.05$ ) forms of cheating. Table 3 shows that years of involvement in sport were negatively related with the justification of the first form of cheating $(\beta=-0.16, p<0.01)$, student athletes with the least sports experience justified this form of cheating most. However, sports experience was positively related with the justification of the second $(\beta=0.12$, $p<0.05)$ and the third $(\beta=0.15, p<0.01)$ forms of cheating. Table 3 shows that moral disengagement in sport was the stronger predictor for justification of the second form of cheating $(\beta=0.31, p<0.001)$, slightly less but still significant for the first form $(\beta=0.24, p<0.001)$, and the least significant for the justification of the third form of cheating $(\beta=0.17$, $\mathrm{p}<0.01)$. Moral disengagement in sport was also a predictor for the overall justification of cheating in $\operatorname{sport}(\beta=0.35, \mathrm{p}<0.001)$.

Table 3. Regression analyses predicting justification of cheating in sport $(n=338)$

\begin{tabular}{|c|c|c|c|}
\hline \multirow{2}{*}{ Independent variables } & \multicolumn{3}{|c|}{ Dependent variable: Manipulation with the results of the sports contest ${ }^{1}$} \\
\hline & $\boldsymbol{\beta}$ & SE & $\mathbf{t}$ \\
\hline Gender & 0.02 & 0.08 & 0.30 \\
\hline Year of involvement in sport & -0.16 & 0.05 & $-2.80 * *$ \\
\hline \multirow[t]{2}{*}{ Moral disengagement } & 0.24 & 0.03 & $4.37 * * *$ \\
\hline & \multicolumn{3}{|c|}{ Dependent variable: Athletes' manipulation with the rules of the sports contest ${ }^{2}$} \\
\hline Gender & 0.15 & 0.10 & $2.66^{* *}$ \\
\hline Year of involvement in sport & 0.12 & 0.06 & $2.14 *$ \\
\hline \multirow[t]{2}{*}{ Moral disengagement } & 0.31 & 0.04 & $5.82 * * *$ \\
\hline & \multicolumn{3}{|c|}{ Dependent variable: Provocation against competitors ${ }^{3}$} \\
\hline Gender & 0.13 & 0.12 & $2.26^{*}$ \\
\hline Year of involvement in sport & 0.15 & 0.07 & $2.49 * *$ \\
\hline \multirow[t]{2}{*}{ Moral disengagement } & 0.17 & 0.05 & $2.91 * *$ \\
\hline & \multicolumn{3}{|c|}{ Dependent variable: Overall justification of deception in sports ${ }^{4}$} \\
\hline Gender & 0.15 & 0.15 & $7.96 * * *$ \\
\hline Year of involvement in sport & 0.02 & 0.04 & 0.46 \\
\hline Moral disengagement & 0.35 & 0.03 & $6.96^{* * *}$ \\
\hline
\end{tabular}

Note. ${ }^{*}-\mathrm{p}<0.05,{ }^{* *}-\mathrm{p}<0.01,{ }^{* * *}-\mathrm{p}<0.001 .1-\mathrm{F}=6.56, \mathrm{p}<0.001$, Adjusted $\mathrm{R}^{2}=0.07 .2-\mathrm{F}=16.43, \mathrm{p}<0.001$, Adjusted $^{2}=0.17$. $3-\mathrm{F}=4.93, \mathrm{p}<0.001$, Adjusted $\mathrm{R}^{2}=0.05 .4-\mathrm{F}=19.31, \mathrm{p}<0.001$, Adjusted $\mathrm{R}^{2}=0.14$. 


\section{DISCUSSION}

Our research purpose was, first, to examine the relationship between university athletes' justification of cheating and moral disengagement in sport. It was hypothesized that moral disengagement would predict athletes' more positive evaluation of cheating in sport. It should be noted that this hypothesis was based on research were evaluation of cheating had not been directly researched, but the data obtained verified it, i.e. moral disengagement in sport predicted more positive evaluation of cheating in sport. Other studies revealed links between antisocial behaviour and moral disengagement (Boardley, Kavussanu, 2010; Hodge, Lonsdale, 2011) or that athletes used moral disengagement mechanisms to justify their behaviour (Traclet et al., 2011). Thus, our research complemented to previous research proving that moral disengagement predicted more positive justification of cheating in sport.

Analysing the links between moral disengagement and justification of different forms of cheating in sport, we should consider some unexpected results. Our findings showed that athletes most tended to justify deceptive actions associated with the provocation against competitors, they least tended to justify manipulation with the results of the sports contest. We suggest that it is partly logical because the first form of cheating included deceptive actions which could be evaluated as part of contest activities by some of the athletes. Meanwhile, the forms of cheating as using forbidden drugs, betting on the outcome of the sports fight are usually regarded negatively. Incidentally, in the coaches opinion, such cheating cases are not very common in sports (Sukys, Nickus, 2010), but they are quite common in the sports world (Preston, Szymanski, 2003). On the other hand, our research revealed that moral disengagement much more predicted justification of such cheating than provocation against competitors.

The study also sought to determine the relationship between athletes' assessment of cheating in sport and personal factors: gender, sports mastery and sports experience. In the aspect of gender, it should be noted that male athletes more justified cheating in sport. This partly confirmed the findings of other researchers claiming that attitudes of males and females towards antisocial behaviour in sports activities might be different (von Roenn et al., 2004), or that moral values in sports for female athletes are more important (Sukys, Jansoniene, 2012). However, analysing different form of cheating, it appeared that both males and females equally little justified deceptive actions linked with the manipulation with the results of the sports contest. Thus, the hypothesis that male athletes justified cheating in sports activities more was partly confirmed. At the beginning of the study we also hypothesized that the evaluation of cheating in sports activities would not be linked to athletes' sport experiences. The data obtained did not reveal the links between athletes' sports experience and the evaluation cheating in sport. However, we found differences analysing the evaluation of different forms of cheating. Deceptive actions associated with athletes' manipulation with the rules of the sports contest were more justified by athletes with more experience in sport. However, it was unexpected that deceptive actions linked to manipulation with the results of the sports contest were most justified by athletes with the least experience in sports activities. In conclusion, we can say that the hypothesis associated with sports experience raised at the beginning of the study was partially confirmed. Nevertheless, some recent studies suggested that sports experience positively predicted antisocial behaviour in sport (Sagar et al., 2011). So, the factor of sports experience remains relevant in further studies to clarify athletes' personal behaviour related to deceptive actions. We should also not eliminate sports mastery as an independent factor though our investigation did not reveal links between it and the evaluation of cheating in sport.

\section{CONCLUSION AND PERSPECTIVES}

Our study revealed the relationship between moral disengagement in sport and athletes' justification of cheating in sport. Analysing different forms of cheating it was found that moral disengagement in sport was a stronger predictor for the justification of such deceptive actions that are linked to athletes' manipulation of the rules of the sport and manipulation with the results of the sports contest. It was established that male student athletes more justified cheating in sport. Research results did not reveal relationship between overall justifications of cheating by years of involvement in sport. However, the analysis of the justification 
of different forms of cheating showed that students with less sports experience more justified deceptive actions linked to the manipulation with the results of the sports contest, and, on the contrary, less justified other forms of cheating in sport.

As there are eight mechanisms of moral disengagement (Bandura, 1991) and different types of antisocial behaviour associated with the frequency and type of moral disengagement mechanisms (Traclet et al., 2011), further research should focus on separate moral disengagement mechanisms, not only on the overall scores.

\section{REFERENCES}

Bandura, A. (1991). Social cognitive theory of moral thought and action. In W. M. Kurtines, J. L. Gewirtz (Eds.), Handbook of Moral Behavior and Development: Theory, Research, and Applications (Vol. 1, pp. 45-103). Hillsdale, NJ: Lawrence Erlbaum Associates.

Boardley, I. D., Kavussanu, M. (2007). Development and validation of the moral disengagement in sport scale. Journal of Sport \& Exercise Psychology, 29, 608-628.

Boardley, I. D., Kavussanu, M. (2010). Effects of goal orientation and perceived value of toughness on antisocial behavior: The mediating role of moral disengagement. Journal of Sport \& Exercise Psychology, 32 (2), 176-192.

Boardley, I. D., Kavussanu, M. (2009). The influence of social variables and moral disengagement on prosocial and antisocial behaviors in field hockey and netball. Journal of Sports Sciences, 27 (8), 843-854.

Boardley, I. D., Kavussanu, M. (2008). The moral disengagement in sport scale - short. Journal of Sports Sciences, 26 (14), 1507-1517.

Budreikaitè, A., Adaškevičienė, E. (2010). Sportuojančių ir nesportuojančiu paauglių požiūris i vertybes ir jų prasmès suvokimą. Ugdymas. Kūno kultūra. Sportas, 1 (76), 13-20.

Dicker, M., Uehara, L., Lima, C. (2011). Deception, individual differences and penalty kicks: Implications for goalkeeping in association Football. International Journal of Sports Science \& Coaching, 6 (4), 515-521.

Fraleigh, W. (2003). Intentional rules violations - one more time. Journal of the Philosophy of Sport, 30, $166-176$

Genys, D. (2011). Nuo vertybinio idealizmo iki pragmatinès komercijos? Olimpinès vertybès ir jų kaita. Sporto mokslas, 1 (63), 5-12.

Hodge, K., Lonsdale, Ch. (2011). Prosocial and antisocial behavior in sport: The role of coaching style, autonomous vs. controlled motivation, and moral disengagement. Journal of Sport \& Exercise Psychology, 33 (4), 527-547.

Hsu, L. (1997). Cheating and sports rules. International Olympic Academy: 7th Postgraduate Session. Greece.

Kahn, J. H. (2006). Factor analysis in counseling psychology research, training, and practice: Principles, advances, and applications. The Counseling Psychologist, 34, 684-718.

Loland, S. (2002). Fair Play in Sport: A Moral Norm System. London: Routledge.

Loland, S. (2005). The varieties of cheating - comments on ethical analyses in sport. Sport in Society, 8 (1), 11-26.

Mewett, P. G. (2002). Discourses of deception: Cheating in professional running. The Australian Journal of Anthropology, 13 (3), 292-308.

Moran, A., Guerin, S., MacIntyre, T., McCaffrey, N. (2004). Why do athletes cheat? An Investigation of Irish Athletes' Understanding of, and Attitudes to Cheating Behaviour (including doping) in Sport. Commissioned research report to Irish Sports Council, 9 February. Ireland: Dublin.

Preston, I., Szymanski, S. (2003). Cheating in contests. Oxford Review of Economic Policy, 19 (4), 612-624.

von Roenn, S., Zhang, J. J., Bennett, G. (2004). Dimensions of ethical misconduct in contemporary sports and their association with the backgrounds of stakeholders. International Sports Journal, 8 (2), 37-54.

Sagar, S., Boardley, I., Kavussanu, M. (2011). Fear of failure and student athletes' interpersonal antisocial behaviour in education and sport. British Journal of Educational Psychology, 81, 391-408.

Sukys, S., Jansonienė, A. J. (2012). Relationship between athletes' values and moral disengagement in sport, and differences across gender, level and years of involvement. Ugdymas. Küno kultūra. Sportas, 1 (84), 55-61.

Sukys, S., Nickus, E. (2010). Coaches' attitudes towards deception in sports activities. Sporto mokslas, 1 (59), 28-35.

Traclet, A., Romand, P., Moret, O., Kavussanu, M. (2011). Antisocial behavior in soccer: A qualitative study of moral disengagement. International Journal of Sport and Exercise Psychology, 9, 143-155.

Zaksaite, S. (2012 a). Olimpinių žaidynių šviesa ir šešèliai apgaulingo elgesio sporte aspektu. Sporto mokslas, 3 (69), 14-19.

Zaksaite, S. (2012 b). Sukčiavimo sporto srityje paplitimas ir prevencijos problemos: daktaro disertacija. Vilnius: Vilniaus universitetas. 


\title{
MORALINIO PATEISINIMO IR SPORTININKŲ ASMENINIŲ VEIKSNIŲ SĄSAJOS SU APGAULĖS SPORTINĖJE VEIKLOJE VERTINIMU
}

\author{
Saulius Šukys \\ Lietuvos sporto universitetas, Kaunas, Lietuva
}

\begin{abstract}
SANTRAUKA
Tyrimo pagrindimas ir hipotezė. Tyrimu keliama hipotezè, kad moralinis pateisinimas bus susijęs su sportininku palankesniu apgaulès sportinèje veikloje vertinimu. Taip pat kelta antra hipotezè, kad apgaulès sportinèje veikloje pateisinimas bus susijęs su lytimi ir atitinkamai nesisies su sportine patirtimi.

Tikslas - išsiaiškinti moralinio pateisinimo ir sportininkų asmeninių veiksnių (lyties, sportinio meistriškumo ir sportinès patirties) sąsajas su apgaulės sportinėje veikloje vertinimu.

Metodai. Tiriamuju kontingentą sudare 338 (246 vaikinai ir 92 merginos) sportuojantys studentai, parinkti iš ¡vairių Lietuvos universitetu. Tiriant studentus naudota Apgaulès sportineje veikloje vertinimo skalè (Sukys, Nickus, 2010) ir Moralinio pateisinimo sportinèje veikloje trumpoji skalè (MDSS-S; Boardley, Kavussanu, 2008).

Rezultatai. Nustatyta sąsaja tarp sportininkų lyties ir apgaulès sportineje veikloje vertinimo $(\beta=0.15, p<0.01)$. Tyrimo duomenimis, vaikinai labiau pateisina apgaulę sportinejje veikloje. Sportinė patirtis nėra susijusi su bendru apgaulès sportineje veikloje vertinimu. Nustatyta sąsaja tarp moralinio pateisinimo ir apgaulès sportineje veikloje vertinimo $(\beta=0.35, \mathrm{p}<0.001)$.

Aptarimas ir išvados. Tyrimas atskleidè sąsajas tarp moralinio pateisinimo ir sportuojančių studentų apgaulès sportineje veikloje vertinimo. Gilinantis į atskiras apgaulès formas nustatyta, kad moralinio pateisinimo sportinèje veikloje veiksnys labiausiai prognozuoja tokių apgaulès sportinėje veikloje formų kaip sportininkų manipuliacijos sportinès kovos taisyklemis ir manipuliacijos sportinès kovos baigtimi pateisinimą. Sportuojantys studentai vyrai labiau pateisina apgaulę sportinèje veikloje. Tyrimas neatskleidé sąsajų tarp sportinès patirties ir bendro apgaulès sportinėje veikloje vertinimo. Visgi gilinantis ị skirtingų apgaulès formų vertinimą atskleista, kad mažesnę sportinę patirti turintys studentai labiau pateisina apgaulingus veiksmus, susijusius su manipuliacijomis sportinès kovos baigtimi, ir mažiau kitas apgaulès formas.
\end{abstract}

Raktažodžiai: sportinė veikla, apgaulès sportinèje veikloje vertinimas, moralinis pateisinimas.

Gauta 2013 m. liepos 17 d.

Received on 17 July, 2013

Priimta 2013 m. rugsèjo $9 \mathrm{~d}$.

Corresponding author Saulius Šukys

Accepted on 9 September, 2013

Lithuanian Sports University

Sporto str. 6, LT-44221 Kaunas

Lithuania

Tel +370 37302638

E-mail saulius.sukys@1su.1t 